\title{
Pengaruh Kebijakan Struktur Modal terhadap Kinerja Emiten Syariah di Jakarta Islamic Index
}

\author{
Muhammad Arif \\ Institut Agama Islam Negeri Padangsidimpuan \\ E-mail: arif.chan1101@gmail.com \\ Jl. H.T. Rizal Nurdin, Km. 5,5 Sihitang, Padangsidimpuan, Sumatera Utara
}

\begin{abstract}
Abstrak
Penelitian ini bertujuan untuk menganalisis kebijakan struktur modal terhadap kinerja emiten di Jakarta Islamic Index (JII). Struktur modal pada emiten penerbit saham syariah berbeda dengan emiten non syariah karena adanya pembatasan utang berbasis bunga terhadap aset perusahaan yang diterapkan saat screening saham syariah. Metode yang digunakan adalah kuantitatif deskriptif verifikatif melalui pendekatan Partial Least Square (PLS). Populasi penelitian adalah seluruh emiten yang terdaftar di JII periode 2014 s.d 2018. Sampel yang digunakan adalah emiten yang konsisten terdaftar pada JII. Hasil penelitian membuktikan bahwa struktur modal yang digunakan oleh emiten syariah di JII memiliki pengaruh positif sebesar 52.1\%. Hasil ini membuktikan bahwa emiten syariah di JII boleh mempergunakan komponen struktur modal yaitu utang dengan syarat harus dapat mendorong kinerja perusahaan dan bilamana utang yang digunakan hanya sebagai komponen pendorong nilai perusahaan (harga saham) tanpa dibuktikan dengan kinerja maka hasil yang didapatkan akan berdampak negative, hasil ini sesuai dengan trade off theory.
\end{abstract}

Kata kunci: Struktur Modal, Profitabilitas, Nilai Perusahaan

\begin{abstract}
This study aims to analyze the capital structure policy on the performance of issuers listed on the Jakarta Islamic Index (JII). The capital structure of Islamic stock issuers has different from non-Islamic issuers due to interest-based debt restrictions on company assets applied at the screening of Islamic stocks. The method used in this research is quantitative descriptive verification, which is analyzed the Partial Least Square (PLS). The population is all issuers registered in the JII for the period 2014 to 2018. The sample used that are consistently listed on the JII. The results study prove that the capital structure used by Islamic issuers in the JII has a positive effect of $52.1 \%$. The results of this study prove that Islamic issuers in the JII may use the capital structure component, namely debt on the condition that it is able to encourage company performance and if debt is used only as a driving component of firm value (stock price) without being proven by performance, the results obtained will have a negative impact, this study are in accordance with the trade off theory.
\end{abstract}

Keywords: Capital Structure, Profitability, Company Value.

\section{Pendahuluan}

Struktur modal perusahaan telah menjadi topik paling diperdebatkan dikalangan akademisi dari awal mula teori M\&M muncul. Franco Modigliani dan 


\section{Pengaruh Kebijakan Struktur Modal terhadap Kinerja Emiten Syariah di Jakarta Islamic Index \\ Muhammad Arif}

Merton H.Miller (1963) sebagai pencetus teori M\&M berpendapat bahwa struktur modal optimal pada perusahaan adalah dengan menggunakan utang sebanyak mungkin pada struktur modalnya. Hasil kajian tersebut mengungkapkan bahwa penggunaan utang dengan komposisi tersebut dapat berindikasi untuk meningkatkan nilai perusahaan, alasan tersebut diperkuat karena adanya faktor pengurangan pajak terhadap beban bunga utang yang ditetapkan.

Teori lain muncul ketika Baxter (1967), Kraus dan Lizenberger (1973) mencoba menguji teori struktur modal yang diusung oleh Franco Modigliani dan Merton H.Miller (1963) dengan mengaitkan asumsi-asumi M\&M terhadap biaya kebangkrutan (financial distress cost). Hal tersebut dapat meningkat sebanding dengan leverage yang digunakan yaitu ketika leverage rendah maka manfaat pengurangan pajak terhadap beban bunga akibat dari penggunaan utang dapat melebihi financial distress cost. Ketika tingkat leverage tinggi maka financial distress cost bisa melebihi manfaat pengurangan pajak akibat penggunaan utang tersebut dan semakin besar utang yang digunakan dalam sruktur modal maka semakin besar pula keuntungan akibat penggunaan utang. Namun, Present Valuefinancial distress cost dan agency juga besar bahkan dapat lebih besar. Teori ini disebut sebagai Trade Off Theory yang menekankan penggunaan utang hanya sampai pada titik optimum yaitu keseimbangan antara financial distress cost dan agency problem serta manfaat penggunaan utang (tax shield) mampu menggambarkan peningkatan nilai perusahaan. Phillips \& Sipahioglu (2004), Qureshi (2007) dalam penelitiannya mengungkap bahwa tingkat utang yang rendah mampu memainkan peranan penting bahkan dapat meningkatkan nilai perusahaan.

M\&M Theory dan Trade Off Theory mendapat kritikan dari Myrez dan Nicholas Majluf dengan mengusung Pecking Order Theory. Menurut Myrez dan Majluf pembiayaan perusahaan memiliki hirarki tersendiri (Phuong, 2017). Pemilihan pembiayaan dimulai dari penggunaan dana internal, kemudian menerbitkan utang jika diperlukan dan terakhir penerbitan ekuitas (Myers \& Majluf, 2005). Alasan penggunaan hirarki dari pendanaan internal tersebut adalah karena ketika suatu perusahaan menjual obligasi atau saham ke public untuk menambah kas perusahaan bisa jadi sangat mahal sehingga ini menjadi alasan paling kuat untuk menghindari pendanaan tersebut. Menurut Shahar \& Manja (2018) perusahaan yang memiliki laba yang tinggi menunjukkan bahwa perusahaan tersebut memiliki dana internal yang cukup untuk membiayai operasional perusahaannya tanpa bergantung pada dana eksternal, sehingga perusahaan tersebut memiliki sedikit utang ataupun tanpa utang sama sekali. 
Penelitian ini dilatarbelakangi oleh perdebatan akademik yang terjadi antara teori M\&M, Trade Off Theory dan Pecking Order Theory. Diluar ketiga teori tersebut, muncullah teori yang memiliki khas tersendiri yang diterapkan pada emiten Syariah yaitu Sharia Screening. Sharia Screening merupakan suatu proses penyeleksian perusahaan agar saham perusahaan yang diperjualbelikan dapat masuk dalam kategori Daftar Efek Syariah (DES). Proses ini menggunakan dua cara penyeleksian yaitu dengan cara Business Screening dan Financial Screening. Business Screening digunakan untuk memfilter kegiatan-kegiatan usaha yang dilakukan di dalam perusahaan seperti perjudian dan sejenisnya, perdagangan barang haram, jasa keuangan yang mengandung unsur ribawi serta kegiatan usaha yang dapat merusak moral dan menimbulkan kemudharatan. Sedangkan Financial Screening merupakan penyeleksian terhadap keyangan perusahaan, yaitu total utang berbasis ribawi dibandingkan dengan total asset perusahaan tidak lebih dari $45 \%$ dan pendapatan non halal dibandingkan dengan total pendapatannya tidak melebihi 10\%. Penetapan financial screening menjadi salah satu upaya yang dilakukan untuk memfilterisasi emiten penerbit saham agar tetap patuh dan tetap dapat dikategorikan sebagai emiten Syariah. Financial Screening juga sangat berkaitan erat dengan pembentukan komponen stuktur modal perusahaan.

Komposisi struktur modal yang memiliki komponen utang lebih sedikit tentu sangat dihargai oleh para investor karena risiko yang dihadapi perusahaan tentu lebih rendah dan kinerja perusahaan yang tinggi selalu menjadi keinginan para investor, karena perusahaan dengan kinerja yang baik dianggap mampu menyejahterakan dan hal ini menjadi sangat menarik perhatian para investor untuk dapat berinvestasi pada perusahaan tersebut. Kinerja perusahaan menjadi faktor yang sangat fundamental juga bagi investor untuk menentukan pengambilan keputusan apakah perusahaan tersebut layak untuk tempat berinvestasi ataupun tidak (Santoso, 2017).

Penelitian ini akan menguji teori struktur modal yang diterapkan emiten syariah yang tercatat dalam Jakarta Islamic Index (JII) periode 2015-1019. Objek penelitian ini dipilih karena emiten yang tercatat di JII memiliki tingkat likuiditas yang tinggi dan struktur modal yang dimiliki sangat berbeda dari emiten non syariah pada umumnya. Emiten yang tercatat di JII memiliki pembatasan terhadap komponen struktur modal yaitu utang. Pembatasan tersebut disebut sebagai financial screening yang mengatur penggunaan utang berbasis bunga (ribawi) terhadap total asset emiten syariah dan untuk utang non bunga tidak ada batasan.

Berdasarkan hasil pengamatan peneliti dari ikhtisar laporan keuangan emiten syariah yang tercatat di JII, menunjukkan bahwa rata-rata struktur modal yang diukur 


\section{Pengaruh Kebijakan Struktur Modal terhadap Kinerja Emiten Syariah di Jakarta Islamic Index \\ Muhammad Arif}

menggunakan rasio Debt Equity dan Debt to Asset yang dimiliki oleh emiten syariah menunjukkan hasil yang berfluktuatif bahkan cenderung menurun setiap tahunnya bahkan kinerja yang diukur dengan rasio profitabilitas juga mengalami kondisi yang sama. Artinya apakah kebijakan struktur modal emiten syariah berpengaruh terhadap kinerja atau tidak. Menurut Ross (2015) utang merupakan sebuah pengungkit, hal ini menjelaskan sebuah indikasi bahwa penggunaan utang dapat melipatgandakan keuntungan yang potensial bagi para pemegang saham, akan tetapi sebaliknya utang juga dapat memiliki potensi yang dapat memicu kerugian, kesulitan keuangan, maupun kegagalan perusahaan. Brigham (2001) juga menjelaskan semakin rendah kepemilikan utang yang diukur dengan debt ratio maka risiko yang dihadapi perusahaan semakin berkurang dan sebaliknya ketika kepemilikan utang perusahaan tinggi, maka risiko yang ditanggung semakin tinggi pula, dan bahkan utang yang berlebihan menyebabkan perusahaan kesulitan keuangan serta menghambat perkembangan perusahaan.

\section{Gambar 1}

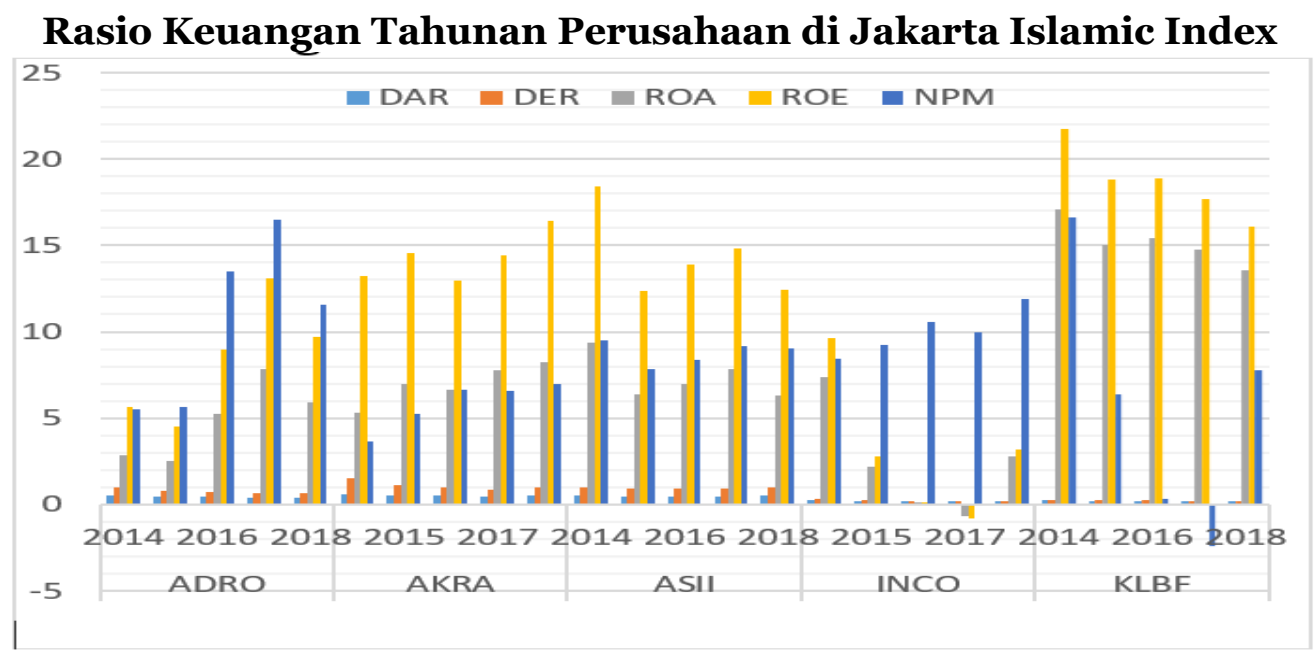

\section{Sumber: www.idx.co.id (data diolah)}

Penetapan sharia screening secara kuantatif pada emiten syariah menunjukkan pembahasan yang sama dengan teori struktur modal (capital structure) karena adanya pola bagaimana seni perusahaan dalam membentuk kombinasi struktur modal yang pas untuk perusahaannya. Penelitian ini menarik untuk dikaji kembali karena masih terdapat inkonsistensi dari para pakar, peneliti dan para akademisi. Penelitian struktur modal umumnya dilakukan pada emiten non syariah ataupun perusahaan konvensional, perbankan syariah dan Non syariah. Untuk itu perlu dilakukan penelitian lanjutan terhadap emiten syariah yang tercatat di Jakarta Islamic Index (JII) tahun 2015-2018. 


\section{Kajian Teoritik}

\section{Struktur Modal Perusahaan}

Struktur modal (capital structure) adalah sebuah istilah yang mengacu pada gabungan modal dan utang suatu perusahaan. Pada laporan keuangan posisi struktur modal berada pada posisi kanan neraca yang dipeuntukkan untuk memenuhi operasional suatu perusahaan. Struktur modal juga dapat dipahami sebagai perbandingan modal asing dan modal sendiri (Suriani, 2014). Hal ini menjadi sangat krusial, karena struktur modal dapat berpengaruh terhadap kualitas kinerja dari sebuah perusahaan. Terdapat eberapa defenisi yang menjelaskan pengertian struktur modal oleh beberapa tokoh ekonom sebagai berikut;

1. Frank J. Fabozzi(2003) dan Sthephen A. Ross(2015) menjelaskan bahwa struktur modal merupakan kombinasi utang dan ekuitas yang digunakan untuk pembiayaan proyek-proyek maupun kegiatan operasional di dalam perusahaan.

2. H. Kent Baker dan Gerarld S. Martin (2011), berpendapat bahwa struktur modal adalah pembiayaan yang dipergunakan oleh perusahaan bersumber dari utang, ekuitas dan hybrid securities, yang digunakan perusahaan sebagai pembiayaan terhadap aset, operasional, dan pertumbuhan di masa yang akan datang.

3. Menurut Myers dan Majluf struktur modal merupakan sebuah elemen yang terdiri dari komponen utang jangka panjang (Long-Term Debts) dan Ekuitas yang bersatu membentuk nilai perusahaan.

Berdasarkan beberapa defenisi yang dikemukakan oleh beberapa tokoh tersebut, penulis dalam hal ini menyimpulkan bahwa struktur modal adalah gabungan permodalan dari luar perusahaan berupa utang jangka panjang, utang bank, pembiayaan dari bank konvensional maupun syariah Syariah, serta penerbitan obligasi/sukuk dan dari dalam perusahaan dengan menggunakan laba ditahan dan ekuitas. Struktur modal menjadi point penting bagi perusahaan dan merupakan hal yang paling dasar juga di dalam manajemen keuangan. Seorang manajer keuangan setidaknya harus mampu memperhatikan cara-cara perusahaan memperoleh bahkan mengelola pendanaan jangka panjang yang diperlukan sebagai pendukung untuk investasi jangka panjang. Seorang Manajer keuangan juga harus dapat memperhatikan dan memiliki kemampuan dalam bidang manajemen keuangan. Seperti, berapa banyak jumlah utang yang harus digunakan oleh perusahaan, bagaimana konsep dan kombinasi antara utang dan ekuitas yang terbaik bagi perusahaan, serta model seperti apa yang dapat diterapkan bahkan mampu meningkatkan kinerja perusahaan baik ditinjau dari segi profitabilitas dan nilai perusahaannya. Selanjutnya antara 


\section{Pengaruh Kebijakan Struktur Modal terhadap Kinerja Emiten Syariah di Jakarta Islamic Index

penggunaan utang dan ekuitas, sumber manakah yang bernilai paling murah untuk digunakan oleh perusahaan.

\section{Kinerja Perusahaan}

Kinerja perusahaan merupakan salah satu hal yang sangat fundamental bagi para investor dalam menilai sebuah perusahaan. Kinerja perusahaan menjadi faktor yang menentukan pengambilan keputusan bagi seorang investor apakah perusahaan tersebut dapat dijadikan sebagai tempat untuk berinvestasi (Santoso, 2017). Dalam Standar Akuntansi Keuangan (SAK) kinerja perusahaan dapat dianalisa melalui pengukuran dan pengevaluasian laporan keuangan. Informasi laporan keuangan periode masa lampau sering sering sekali digunakan guna memprediksi maupun menghitung persentase kinerja dari sebuah perusahaan. Laporan keuangan yang diterbitkan perusahaan merupakan cerminan dari sebuah kinerja keuangan perusahaan. Laporan keuangan juga merupakan akhir proses dari akuntansi dengan tujuan untuk memberikan informasi keuangan yang dapat menjelaskan kondisi perusahaan dalam satu periode. Pengukuran kinerja keuangan perusahaan merupakan salah satu indikator yang digunakan investor untuk menilai suatu perusahaan dari harga pasar saham tersebut du Bursa Efek Indonesia. Semakin baik kinerja perusahaan maka semakin tinggi return yang akan diperoleh investor. Umumnya investor akan mencari perusahaan yang mempunyai kinerja terbaik dan menanamkan modalnya kepada perusahaan tersebut.

Pengukuran kinerja keuangan perusahaan dilakukan untuk melihat apakah hasil pencapaian perusahaan tercapai sesuai dengan perencanaan atau tidak. Dengan melihat adanya peningkatan kinerja keuangan suatu perusahaan berarti perusahaan tersebut telah mampu menigkatkan serta mencapai tujuan awal dari sejak perusahaan tersebut didirikan.Bagi sebuah perusahaan, menjaga dan meningkatkan kinerja keuangan adalah suatu keharusan agar saham yang diterbitkan oleh perusahaan tetap dapat eksis dan tetap memiliki diminati oleh investor. Penggunaan informasi kinerja perusahaan digunakan investor untuk menilai performa dan pengembalian saham yang akan diperoleh di masa mendatang. Kinerja perusahaan sangat berkaitan erat dengan hasil perolehan dari pemanfaatan sumber daya yang digunakan oleh perusahaan untuk mencapai tujuan dari sebuah perusahaan.

Kinerja perusahaan merupakan hasil yang didapatkan dari kegiatan operasional dan manajemen sebuah perusahaan. Umumnya kinerja perusahaan diukur berdasarkan laba bersih yang didapatkan.Pengukuran kinerja diukur dengan menggunakan Profitability Ratio yang dapat mengukur efektivitas menajemen 
perusahaan secara menyeluruh yang ditujukan oleh besar dan kecilnya tingkat keutungan yang diperoleh perusahaan baik dari hasil kegiatan usahanya maupun dari investasi. Profitabilitas merupakan hasil akhir dari sejumlah kebijakan dan keputusan manajemen perusahaan. Rasio profitabilitas biasanya digunakan sebagai indikator pengukur keberhasilan suatu perusahaan dan indikator yang dapat mengevaluasi kinerja manajer.Selain diukur dengan profitabilitas, kinerja perusahaan juga dapat ditinjau dari perkembangan harga saham perusahaan, laba per lembar saham (EPS) dan return saham.Harahap (2010) berpendapat bahwa rasio profitabilitas adalah rasio yang dapat menggambarkan kemampuan sebuah perusahaan dalam hal pencapaian laba melalui semua kemampuan baik dari segi sumber yang ada seperti kegiatan penjualan, kas, modal, jumlah karyawan, jumlah cabang, dan sebagainya. Pada dasarnya rasio ini adalah rasio yang menggambarkan kinerja perusahaan dengan menunjukkan efisiensi dari sebuah perusahaan (Kasmir, 2010). Penggunaan rasio profitabilitas sebagai penilaian pengembalian investasi perusahaan berdasarkan tingkat sumber daya dan asset relatifnya, rasio ini tentunya dapat dipergunakan oleh investor dan kreditor sebagai pertimbangan kepada perusahaan. Dengan kata lain, rasio ini dapat digunakan untuk menilai apakah perusahaan tersebut mampu menghasilkan laba operasional yang cukup dari total aset perusahaan (Lesambo, 2018).

Konsep profitabilitas dalam teori keuangan sangat sering digunakan sebagai indicator fundamental perusahaan dan umumnya profitabilitas memiliki kaitan terhadap nilai perusahaan yang diukur melalui indicator harga saham. Hubungan kausalitas yang terjadi tersebut menunjukkan bahwa ketika kinerja manajemen sebuah perusahaan diukur dengan dimensi-dimensi profitabilitas dalam kondisi yang baik, maka hal tersebut mampu memberikan dampak yang positif terhadap keputusan investor di pasar modal untuk berinvestasi dalam bentuk penyertaan modal, dan demikian juga kaitannya dengan kreditor dalam hal pendanaan melalui utang (Harmono, 2014). Ebaid (2009) memaparkan pengukuran kinerja perusahaan berbasis akuntansi adalah dengan mengukur Return On Equity (ROE), Return On Asset (ROA). Ogebe menyatakan bahwa kinerja perusahaan juga dapat diukur dengan menggunakan rasio profitabilitas dan efisiensi yaitu laba atas ekuitas (ROE), laba atas investasi (ROI), perputaran aset dan rasio biaya operasional. Brigham dan Houston (2010), Ross et.al (2015) berpendapat bahwa perhitungan rasio profitabilitas adalah dengan Net Profit Margin (rasio atas penjualan), return on assets (tingkat pengembalian total aktiva), return on common equity (tingkat pengembalian ekuitas saham biasa) dan basic earning power (kemampuan dasar untuk menghasilkan laba). 


\section{Pengaruh Kebijakan Struktur Modal terhadap Kinerja Emiten Syariah di Jakarta Islamic Index \\ Muhammad Arif}

Lesambo (2018) juga menambahkan cara perhitungan rasio profitabilitas adalah dengan menggunakan beberapa jenis rasio yaitu effective tax rate, return on sales, return on operating expenses (Berry Ratio),return on total cost, return on capital employed. Harmono (2014) dalam hal pengukuran profitabilitas dapat diukur dengan menggunakan Net Profit Margin (NPM), Gross Profit Margin (GPM), Return On Asset (ROA), Return On Equity (ROE), Earning Per Share (EPS), Return On Investment (ROI).

Kesimpulan dari pengukuran profitabilitas perusahaan adalah semakin tinggi persentase rasio profitabilitas perusahaan, maka semakin baik dan hasil tersebut dapat menggambarkan kemampuan perusahaan dalam memperoleh keuntungan (Fahmi, 2013). Kegiatan memaksimalkan keuntungan perusahaan merupakan tujuan dari seluruh perusahaan. Kinerja perusahaan yang digambarkan dengan rasio profitabilitas menjadi salah satu faktor yang mampu mempengaruhi maupun dipengaruhi oleh struktur modal perusahaan. Hamid, et.al (2015) dalam penelitiannya mengungkapkan bahwa struktur modal berpengaruh secara negatif terhadap profitabilitas. Temuan ini menjelaskan bahwa perusahaan yang memiliki laba bersih tinggi lebih bergantun kepada pembiayaan ekuitas yang didapatkan dari laba ditahan sebagai pilihan utama dalam pengambilan keputusan terkait struktur modal.Jaisinghani dan Kanjilal (2015) memaparkan hasil penelitian yang dinilai kontradiktif dengan kesimpulan bahwa dengan penambahan utang di dalam perusahaan mampu mendongkrak profitabilitas perusahaan. hal tersebut dibuktikan karena perusahaan manufaktur yang digunakan peneliti sebagai objek penelitiannya memiliki utang yang rendah. Dengan demikian terkait penambahan utang pada struktur modal perusahaan memiliki dampak yang positif terhadap kinerja perusahaan. Hasil ini penelitian ini mendukung trade off theory (Kanjilal, 2017).

\section{Nilai Perusahaan}

Secara normatif, pengelolaan keuangan yang dilakukan oleh manajemen keuangan adalah untuk meningkatkan nilai perusahaan yang tercermin dari harga pasar sahamnya dan juga turut menjaga stabilitas keuangan dalam keadaan yang selalu terkendali, serta memperkecil risiko perusahaan di masa sekarang dan yang akan datang (Fauziah, 2017). Bartley (2017) mengungkapkan bahwa manajemen keuangan perusahaan juga memiliki tujuan utama yang harus dicapai yaitu maximization wealth of stockholders. Maksimalisasi tersebut dapat dilakukan dengan beberapa cara, antara lain adalah dengan cara efisiensi pelaksanaan operasional perusahaan. Hasil dari efisiensi pelaksanaan tersebut mampu mengacu pada hasil 
akhir dari kegiatan perusahaan selama satu periode. Penilaian tersebut bertujuan sebagai bahan evaluasi perusahaan dalam meningkatkan nilai perusahaan.

Nilai perusahaan yang tinggi merupakan harapan para investor karena dapat menunjukkan tingkat kesejahteraan para pemegang saham. Harga saham ditentukan oleh reaksi dan respon pasar terkait informasi mengenai perusahaan. Meskipun pergerakan saham sulit dikendalikan oleh perusahaan, perusahaan mempertahankan harga saham seoptimal mungkin dalam menjaga citra perusahaan di mata investor. Nilai perusahaan juga merupakan persepsi investor terhadap perusahaan yang biasanya dikaitkan dengan harga saham. Nilai perusahaan menunjukkan tingkat kepercayaan pasar terhadap prospek perusahaan di masa depan. Dari sudut pandang yang berbeda, investor berpandangan bahwa nilai perusahaan merupakan harga jual yang dianggap layak bagi seorang calon investor sehingga mau membayarnya dan jika perusahaan tersebut dijual dan emiten yang menjual sahanya ke masyarakat, justru dengan melihat nilai perusahaan sebagai harga yang diperjualbelikan di bursa efek(Fuad, 2006). Malik dan Hunt menjelaskan secara umum bahwa nilai perusahaan adalah nilai dari total kapitalisasi perusahaan, yaitu ekuitas ditambah utang bersih, yang juga biasa dikenal sebagai nilai pasar (Hunt, 2011). Nilai tersebut juga mencerminkan nilai bisnis keseluruhan perusahaan yang dapat dialokasikan para investor dan pemegang instrumen utang perusahaan (Malik, 2015). Nilai perusahaan sangat penting karena kenaikan nilai perusahaan akan diikuti oleh kemakmuran pemegang saham perusahaan tersebut juga (Fauziah, 2017). Semakin tinggi harga saham perusahaan berdampak pada semakin meningkatnya nilai perusahaan (Soehadi, 2012).

Pengukuran terhadap nilai perusahaan telah mengalami banyak perkembangan, dari yang sifatnya konvensional sampai pada yang lebih modern dan mempunyai kemampuan yang lebih baik dalam pengukuran nilai perusahaan. Oleh karena itu, berbagai pihak yang berkepentingan dengan perusahaan dapat melakukan penilaian terhadap nilai perusahaan menggunakan berbagai pendekatan sesuai dengan kebutuhannya masing-masing. Nilai perusahaan juga dapat dilihat dengan memperhatikan perkembangan harga saham pada bursa efek. Nilai perusahaan dapat diukur dengan menggunakan Price Earning Ratio (PER), Price Book Value (PBV), Earning Per Share (EPS), Price, dan Tobin's Q. Price Earning Ratio (PER) merupakan rasio yang mengukur perbandingan harga saham dengan keuntungan yang diperoleh pemegang saham. Semakin besar PER maka semakin besar pula kemungkinan perusahaan untuk tumbuh sehingga dapat meningkatkan nilai perusahaan. 


\section{Pengaruh Kebijakan Struktur Modal terhadap Kinerja Emiten Syariah di Jakarta Islamic Index \\ Muhammad Arif}

Price Book Value (PBV) merupakan rasio harga saham per lembar terhadap nilai buku per lembar saham perusahaan. Nilai buku per lembar saham menunjukkan aset bersih per lembar saham yang dimiliki oleh pemegang saham. Pada perusahaan yang akan melakukan penawaran saham perdana (Initial Public Offering) sering menggunakan Book Value sebagai alat ukut menilai harga saham. PBV mempunyai beberapa keunggulan, antara lain:

1. Nilai buku mempunyai ukuran yang relatif stabil yang dapat dibandingkan dengan harga pasar.

2. Nilai buku memberikan standar akuntansi yang konsisten untuk semua perusahaan. PBV dapat dibandingkan antar perusahaan sebagai petunjuk adanya under valuation atau over valuation.

3. Perusahaan dengan nilai earning negatif tidak dapat dinilai menggunakan Price Earning Ratio (PER), dapat dievaluasi menggunakan PBV (Fauziah, 2017)

Earning Per Share (EPS) merupakan perbandingan antara laba bersih setelah pajak pada satu tahun buku dengan jumlah saham yang diterbitkan. EPS juga merupakan rasio yang menunjukkan berapa besar keuntungan yang diperoleh investor atau pemegang saham per lembar sahamnya. Semakin tinggi EPS tentu saha menggembirakan pemegang saham karena besar laba yang disediakan untuk pemegang saham (Musdalifah, 2015).

Tobin's Q adalah nilai pasar dari common stocks dan financial liabilities. Tobin's Q merupakan perbandingan nilai pasar perusahaan dengan investasi bersihnya. Jika harga saham meningkat maka nilai pasar perusahaan juga akan mengalami peningkatan. Tobin's Q merupakan gambaran statistik yang berfungsi sebagai proksi dari nilai prusahaan dari perspektif investor. Nilai Tobin's Q dihasilkan dari penjumlahan nilai pasar saham (market value of all outstanding stock) dan nilai pasar utang (market value of all debt), dibandingkan dengan seluruh modal yang ditempatkan dalam aktiva produksi (replacement value of all production capacity).

Interpretasi nilai Tobin’s Q menurut Sudiyatno dan Puspitasari (2010) sebagai berikut:

1. Tobin's $\mathrm{Q}<1$ menunjukkan bahwa saham dalam kondisi undervalued. Artinya, manajemen telah gagal dalam mengelola aktiva perusahaan dan memiliki potensi pertumbuhan investasi yang rendah.

2. Tobin's $\mathrm{Q}=1$ menggambarkan bahwa saham dalam kondisi average. Dalam hal ini manajemen stagnan dalam mengelola aktiva.

3. Tobin's $\mathrm{Q}>1$ menggambarkan bahwa saham dalam kondisi overvalued. Hal ini manajemen berhasil dalam mengelola aktiva perusahaan (Puspitasari, 2010). 
Menurut Ross dkk (2015) perusahaan dengan rasio Tobin's Q yang tinggi cenderung memiliki peluang investasi yang menarik atau keunggulan bersaing yang signifikan.

Chen (2011) dalam penelitiannya menjelaskan bahwa nilai perusahaan diukur dengan Earning Per Share (EPS), Return on Equity (ROE), Return on Assets (ROA), Tobin's Q, Price Earning Ratio (PER), dan sebagainya. Di dalam teori keuangan, variabel yang menjadi tolak ukur penilaian terhadap perusahaan adalah return saham, harga saham, price earning ratio (PER),abnormal returnserta indikator lain yang mampu menggambarkan harga suatu saham di pasar modal.Harmono (2014) juga menjelaskan konsep nilai perusahaan dibagi atas beberapa indikator pengukuran yaitu, price earning ratio (PER), Earning Per Share (EPS), Price Book Value (PBV), stock return, price, expected return, dan abnormal return.

\section{Metode Penelitian}

Metode penelitian yang digunakan dalam penelitian ini adalah dengan menggunakan metode kuantatif deskriptif verifikatif yang dianalisis menggunakan pendekatan teknik Partial Least Square (PLS) dengan menggunakan Software SmartPLS 3.0. Populasi penelitian ini adalah emiten syariah yang tercatat pada Jakarta Islamic Index periode 2014-2018. Dan Sampel yang digunakan adalah perusahaan yang konsisten tercatat pada Jakarta Islamic Index dengan teknik pengambilan sampel menggunakan metode purposive sampling.

\section{Hasil dan Pembahasan}

\section{Statistik Deskriptif Struktur Modal dan Kinerja Perusahaan}

Analisis statistik deskriptif merupakan sebuah cara yang digunakan untuk menggambarkan data yang telah terkumpul sebagaimana adanya serta dapat dipahami sebagai penjelasan atas konstruk dan indikator-indikator perusahaan yang digunakan dalam analisis kali ini. Adapun jumlah perusahaan yang digunakan sebagai sampel dalam penelitian ini adalah 14 perusahaan yang konsisiten berada pada Jakarta Islamic Index (JII) pada tahun 2014-2018.

Penelitian ini menggunakan data kuartal perusahaan, sehingga total observasi penelitian ini mencapai 280 observasi. Dan untuk lebih jelas mengenai potret struktur modal dan kinerja perusahaan yang konsisten berada pada Jakarta Islamic Index 2014-2018 akan dijelaskan pada tabel berikut ini: 


\section{Pengaruh Kebijakan Struktur Modal terhadap Kinerja Emiten Syariah di Jakarta Islamic Index \\ Muhammad Arif}

Tabel 1

Statistik Deskriptif Struktur Modal dan Kinerja Perusahaan

\begin{tabular}{|l|l|l|l|l|l|l|l|}
\hline & Mean & Median & Min & Max & $\begin{array}{l}\text { S. } \\
\text { Deviation }\end{array}$ & Kurtosis & Skewness \\
\hline DAR & 0.413 & 0.418 & 0.128 & 0.804 & 0.15 & -0.48 & 0.047 \\
\hline DER & 1.022 & 1 & 0.18 & 3 & 0.585 & 0.47 & 0.817 \\
\hline ROA & 9.953 & 7.4 & -3 & 49 & 9.096 & 5.10 & 2.196 \\
\hline ROE & 22.41 & 16.2 & -3.4 & 147.7 & 27.56 & 8.91 & 3.084 \\
\hline NPM & 20.606 & 16.9 & -16 & 96 & 14.8 & 9.83 & 2.376 \\
\hline PRICE & $8,557.73$ & 4,680 & 515 & 55,900 & $10,720.4$ & 4.80 & 2.249 \\
\hline EPS & 258.725 & 148 & -28 & 2,982 & 363.9 & 17.85 & 3.598 \\
\hline PER & 27.67 & 18.7 & -240.8 & $1,094.2$ & 78.51 & 128.58 & 10.039 \\
\hline PBV & 6.599 & 2.7 & 0.4 & 82.4 & 13.60 & 12.22 & 3.591 \\
\hline Obs & 280 & 280 & 280 & 280 & 280 & 280 & 280 \\
\hline
\end{tabular}

\section{Struktur Modal Perusahaan}

Struktur modal yang dimiliki perusahaan dalam periode penelitian 2014-2018 di Jakarta Islamic Index (JII) memiliki rata-rata 0.413 ketika diukur melalui Debt To Assets Ratio (DAR) dapat dipahami bahwa perusahaan-perusahaan yang konsisten pada periode penelitian tersebut memilih mendanai aset perusahaan mereka dengan penggunaan utang sebesar 41\%, dan ketika struktur modal diukur menggunakan Debt To Equity Ratio (DER) memiliki nilai rata-rata 1.022 dan ini dapat dipahami bahwa modal perusahaan lebih didominasi oleh utang sebesar $102 \%$.

Nilai Debt To Asset Ratio (DAR) tertinggi adalah sebesar 0.804 yang digunakan oleh PT. Vale Indonesia Tbk (INCO) pada tahun 2015 pada kuartal ke III, perolehan nilai tersebut dapat dipahami bahwa aset perusahaan PT. Vale Indonesia Tbk (INCO) didanai dengan utang sebesar 80,4 \% dan selebihnya didanai dari sumber lainnya. Sedangkan untuk nilai Debt To Asset Ratio (DAR) terendah adalah sebesar o.128 yang digunakan oleh PT. Perusahaan Gas Negara (PGAS) pada tahun 2016 pada kuartal ke III, perolehan nilai tersebut dapat dipahami bahwa aset perusahaan PT. Perusahaan Gas Negara (PGAS) didanai dengan utang sebesar 12,8\% dan selebihnya didanai dari sumber pendanaan yang bukan berasal dari utang. Nilai Debt Equity Ratio (DER) tertinggi adalah sebesar 3.0 yang digunakan oleh PT. Unilever Indonesia (UNVR) pada tahun 2018 pada kuartal ke III, hal ini mengindikasikan bahwa struktur modal PT. Unilever Indonesia didominasi oleh utang sebesar 300\% dibanding total modal sendiri dan debt to equity ratio (DER) terendah adalah 0.18 yang digunakan 
oleh PT. Vale Indonesia Tbk (INCO) pada tahun 2018 pada kuartal ke I, hal ini mengindikasikan bahwa struktur modal PT. Vale Indonesia Tbk (INCO) memiliki utang yang lebih sedikit dibandingkan dengan total modal yang digunakan. Hal tersebut dapat dilihat bahwa rasio DER berada pada nilai $18 \%$ dari total modal yang digunakan pada perusahaan tersebut.

\section{Kinerja Perusahaan}

Pada penelitian ini kinerja perusahaan diukur dengan dua kriteria yaitu pertama dengan menggunakan rasio profitabilitas dengan indikator Return On Asset (ROA), Return On Equity (ROE) dan Net Profit Margin (NPM) selanjutnya yang kedua adalah dengan menggunakan perhitungan nilai perusahaan dengan indikator Earning Per Share (EPS), Price To Book Value (PBV), Price Earning Ratio (PER), dan harga saham perusahaan. Berikut penjelasan kinerja perusahaan berdasarkan statistik deskriptif di atas.

\section{Profitabilitas}

Kinerja yang dimiliki perusahaan dalam periode penelitian 20142018 di Jakarta Islamic Index (JII) memiliki nilai rata-rata 9.953 ketika diukur dengan Return On Asset (ROA), nilai tersebut dapat dipahami bahwa rata-rata perusahaan yang konsisten terdaftar di JII pada masa periode penelitian menghasilkan profit sebesar 9.95\% dari total aset perusahaan, dan ketika menggunakan Return On Equity (ROE) sebagai ukuran persentase profitabilitas, nilai rata-rata yang dihasilkan adalah 22.41 dan ini dapat dipahami bahwa perusahaan mampu menghasilkan persentase laba dengan jumlah $22,41 \%$ dari total modal yang digunakan oleh perusahaan. Semakin tinggi rasio ini menandakan tingkat return yang diperoleh perusahaan semakin tinggi dan kinerja perusahaan semakin baik. Ketika diukur dengan menggunakan Net Profit Margin (NPM) nilai rata-rata yang didapatkan adalah 20.606, perolehan ini dapat dipahami bahwa perusahaan yang konsisten terdaftar di Jakarta Islamic Index (JII) memperoleh laba bersih setelah pajak sebesar $20.61 \%$ dari total volume penjualan. Semakin tinggi perolehan nilai Net Profit Margin, maka semakin baik pula operasi perusahaan. Nilai Return On Asset (ROA) tertinggi adalah sebesar 49\% yang diperoleh PT. Unilever Indonesia Tbk pada tahun 2018 pada kuartal ke III dan nilai Return On Asset (ROA) terendah adalah -3\% yang diperoleh PT. Vale Indonesia Tbk (INCO) pada tahun 2016 kuartal I. Nilai Return On Equity (ROE) tertinggi adalah sebesar 147.7\% yang diperoleh PT. Unilever Indonesia Tbk pada tahun 2017 kuartal ke II. Selanjutnya nilai Return On Equity (ROE) terendah adalah sebesar $-3.4 \%$ yang diperoleh PT. PT. Vale Indonesia Tbk (INCO) pada tahun 2016 kuartal I. Nilai Net Profit Margin (NPM) 


\section{Pengaruh Kebijakan Struktur Modal terhadap Kinerja \\ Emiten Syariah di Jakarta Islamic Index \\ Muhammad Arif}

tertinggi adalah sebesar 96\% yang diperoleh PT. Telekomunikasi Indonesia (TLKM) pada tahun 2015 kuartal I, dan nilai Net Profit Margin terendah adalah sebesar -16\% yang diperoleh PT. Vale Indonesia Tbk (INCO) pada tahun 2016 pada kuartal I.

\section{Nilai Perusahaan}

Kinerja yang dimiliki perusahaan dalam periode penelitian 20142018 di Jakarta Islamic Index (JII) memiliki nilai rata-rata 258,725 ketika diukur dengan Earning Per Share (EPS) artinya, 14 perusahaan yang menjadi sampel pada penelitian ini memiliki nilai laba per lembar sahamnya sebesar Rp. 258,725. Nilai Price Earning Ratio (PER) pada periode penelitian menunjukkan nilai rata-rata pada angka $27.67 x$, nilai ini merupakan nilai yang digunakan investor sebagai acuan untuk melihat harga saham suatu perusahaan tersebut mahal ataupun murah semakin rendah nilai PER suatu perusahaan, menandakan harga saham perusahaan tersebut murah. Nilai Price Book Value (PBV) pada periode penelitian mencapai nilai rata-rata pada angka 6.59.

Nilai tertinggi dari Earning Per Share (EPS) adalah sebesar Rp. 2.982 yang diperoleh dari PT United Tractors Tbk (UNTR) pada tahun 2018 pada kuartal ke IV dan perolehan nilai Earning Per Share (EPS) terendah adalah di angka Rp. -28 yang diperoleh dari PT Vale Indonesia Tbk (INCO) pada tahun 2017 pada kuartal ke II. Nilai Price Earning Ratio (PER) tertinggi adalah sebesar 1.094x dan perolehan angka tersebut berasal dari PT. Vale Indonesia Tbk (INCO) pada tahun 2016 kuartal ke II dan untuk nilai Price Earning Ratio terendah adalah sebesar -240,8 dan perolehan angka tersebut berasal dari PT Vale Indonesia Tbk (INCO) pada tahun 2016 di kuartal ke III. Selanjutnya nilai Price Book Value (PBV) tertinggi adalah sebesar 82.4 nilai tersebut diperoleh dari PT Unilever Indonesia Tbk (UNVR) pada tahun 2017 pada kuartal ke IV dan nilai Price Book Value (PBV) terendah adalah di angka 0,4 yang diperoleh dari PT Adaro Energy Tbk (ADRO) pada tahun 2015 di kuartal ke III.

\section{Asesmen Model Pengukuran (Outer Model)}

Penelitian ini pada akhirnya menggunakan peubah laten formatif sehingga pengujian dilakukan dengan tiga kriteria yaitu pengujian dengan cara validitas konvergen, kolinearitas antar indikator, dan signifikansi serta relevansi outer weights.

\section{Validitas Konvegen}

Validitas konvergen merupakan pengukuran yang dikakukan untuk menunjukkan sejauh mana sebuah indikator berkorelasi positif terhadap indikator lain pada konstruk yang sama dengan penggunaan indikator yang berbeda (Avkiran, 2018). 
Dalam hal ini indikator-indikator dalam konstruk reflektif dijadikan sebagai cara pendekatan yang berbeda untuk mengukur konstruk yang sama (Sarstedt, et al., 2014). Dengan demikian, indikator-indikator dari konstruk reflektif harus konvergen atau berbagai varians dengan proporsi yang tinggi. Validitas konvergen pada konstruk reflektif menggunakan nilai outer loading. Berbeda dengan validitas konvergen pada konstruk formatif, penentuan validitas konvergen pada konstruk formatif tidak dapat dikerjakan dengan metode reflektif akan tetapi dengan menggunakan analisis redudansi (Santosa, 2018). Analisis redudansi dilakukan dengan mengevaluasi bahwa peubah laten dengan indikator formatif memiliki korelasi yang tinggi dengan peubah laten yang sama yang terbentuk dari indikator reflektif.

Hasil analisis menunjukkan bahwa pada analisis redudansi peubah laten formatif menjadi peubah eksogen untuk peubah laten reflektif. Nilai koefisien jalur dari kedua peubah ini yang akan menentukan ukuran validitas konvergen untuk peubah laten formatif. Hair, dkk menyebutkan bahwa nilai koefisien jalur minimal 0.707 yang termanifestasikan dari nilai $\mathrm{R}^{2}$. Ketika nilai koefisien untuk indikator reflektif kurang dari 0.7 hal tersebut menunjukkan bahwa adanya persoalan dengan validitas konvergen. Hal ini juga menunjukkan indikasi bahwa indikator-indikator yang dimasukkan untuk membangun sebuah konstruk tidak memberikan kontribusi yang cukup untuk menyusun konstruk formatif. Hal ini berarti bahwa konstruk formatifnya harus dicek kembali untuk disesuaikan dengan defenisi teoritis atau konseptualnya.

\section{Uji Kolinearitas Antar Indikator}

Analisis Konvergen menjelaskan bahwa indikator-indikator yang memberntuk konstruk formatif haruslah saling melengkapi. Hal ini berarti bahwa korelasi di antara indikator-indikator yang digunakan harus seminimal mungkin. Dua indikator yang memiliki korelasi tinggi disebut dengan kolinearitas yang menimbulkan persoalan dari dua indikator formatif yang saling berkorelasi dan keadaan ini disebut sebagai kolinearitas jamak (multicollinearity). Persoalan ini berpengaruh kepada perhitungan weight dan tingkat signifikansinya. Salah satu persoalan yang muncul adalah nilai weight yang dihasilkan diluar dugaan dan bahkan mempunyai tanda yang terbalik (Santosa, 2018).

Korelasi yang tinggi pada indikator-indikator formatif pada saat asesmen model pengukuran tidak diinginkan. Tingginya korelasi antara dua buah indikator formatif, yang disebutkan dengan kolineartitas, menunjukkan adanya permasalahan dalam hal interpetasi dan metodologi yang digunakan. Untuk mengakses tingkat kolinearitas, 
penulis menggunakan nilai Variance Inflator Factor (VIF). Menurut Hair dkk, (2018) nilai toleransi sebuah indikator formatif yang memiliki masalah kolinearitas ketika nilai VIF nya diatas 5.Berikut uji kolinearitas antar indikator.

Tabel 2

Nilai Outer VIF

\begin{tabular}{|c|c|c|}
\hline Peubah Laten & Indikator & Nilai VIF \\
\hline \multirow{3}{*}{ Struktur Modal } & DAR & 2.569 \\
\cline { 2 - 3 } & DER & 2.569 \\
\hline \multirow{3}{*}{ Profitabilitas } & ROA & $\mathbf{8 . 3 1 4}$ \\
\cline { 2 - 3 } & ROE & $\mathbf{8 . 2 2 3}$ \\
\cline { 2 - 3 } & NPM & 1.033 \\
\hline \multirow{4}{*}{ Nilai Perusahaan } & EPS & 1.812 \\
\cline { 2 - 3 } & PBV & $\mathbf{1 5 . 5 3 5}$ \\
\cline { 2 - 3 } & PER & 1.015 \\
\cline { 2 - 3 } & PRICE & 2.447 \\
\cline { 2 - 3 } & TOBINS Q & $\mathbf{1 5 . 4 3 4}$ \\
\hline
\end{tabular}

Dari hasil temuan diatas variabel Debt to Asset Ratio, Debt Equity Ratio, Net Profit Margin, Earning Per Share, Price Earning Ratio, dan Price menunjukkan bahwa variabel tersebut terbebas dari masalah kolinearitas. Sedangkan Return On Asset, Return On Equity, Price Book Value dan TobinsQ mempunyai masalah pada kolinearitas. Jika VIF lebih tinggi dari 5, peneliti harus dapat mempertimbangkan menghapus indikator yang sesuai (Yew, et al, 2018) Dalam hal ini ntuk mencegah dan menghilangkan masalah kolinearitas pada model ini maka peneliti menghapus salah satu indicator yang memiliki kemungkinan konstruk yang dibangun dari sisa indicator yang ada tidak lagi valid dan relevan. Pada penelitian ini peneliti menghapus salah satu indikator yang bermasalah. Pada penelitian ini peneliti mengeleminasi variabel Return On Asset dan Price Book Value agar uji selanjutnya dapat dilaksanakan. 
Tabel 3

Nilai outer VIF Setelah Eleminasi

\begin{tabular}{|l|l|l|}
\hline Peubah Laten & Indikator & Nilai VIF \\
\hline \multirow{4}{*}{ Struktur Modal } & DAR & 2.569 \\
\cline { 2 - 3 } & DER & 2.569 \\
\hline \multirow{4}{*}{ Nilai Perusahaan } & ROE & 1.014 \\
\cline { 2 - 3 } & NPM & 1.014 \\
\hline & EPS & 1.811 \\
\cline { 2 - 3 } & PRICE & 2.431 \\
\cline { 2 - 3 } & PER & 1.012 \\
\cline { 2 - 3 } & TOBIN'S Q & 1.484 \\
\hline
\end{tabular}

Dari hasil eleminasi indikator-indikator yang ada di dalam variabel profitabilitas dan nilai perusahaan pada model penelitian ini telah terbebas dari masalah kolinearitas. Setelah melakukan uji tersebut, selanjutnya dilakukan pengujian Signifikansi dan Relevansi Outer Weight pada model penelitian.

\section{Signifikansi dan Relevansi Outer Weight}

Langkah terakhir pada asesmen model pengukuran (outer model) untuk peubah formatif adalah dengan mengukur signifikansi nilai outer weight dan relevansi setiap indikatornya. Outer weight yang dihasilkan dari regresi berganda dengan peubah laten sebagai peubah tak bebas dan indikator-indikator formatifnya sebagai peubah bebas. Dengan konstruknya terbentuk dari kombinasi linear indikatorindikator formatifnya dan nilai outer weight nya, eksekusi regresi berganda akan menghasilkan $\mathrm{R}^{2}=1$, yang berarti bahwa $100 \%$ varians konstruk berasal dari indikator-indikator penyusunnya (Hair,et al, 2017). Nilai outer weight adalah nilai terstandardisasi sehingga bisa dibandingkan satu dengan yang lain. Nilai outer weight menunjukkan kontribusi atau relevansi relatif sebuah indikator terhadap konstruk yang tersusun olehnya. Nilai outer weight dalam model pengukuran formatif biasanya lebih kecil dibanding dengan outer loading dari indikator reflektif.

Jumlah indikator yang membentuk sebuah konstruk formatif tidak ada patokannya. Dengan makin banyaknya indikator yang digunakan, maka cacah indikator yang mempunyai outer weight rendah atau bahkan nol akan meningkat. Berbeda dengan model pengukuran reflektif yang jumlah indikatornya tidak begitu berpengaruh pada evaluasi model pengukuran, model pengukuran formatif 


\section{Pengaruh Kebijakan Struktur Modal terhadap Kinerja Emiten Syariah di Jakarta Islamic Index \\ Muhammad Arif}

mempunyai keterbatasan cacah indikator agar secara statis outer weight nya tetap signifikan. Semakin banyak indikator formatif yang digunakan maka nilai outer weightnya akan menurun. Sejalan dengan hal ini, nilai ratarata outer weight akan menurun dengan makin banyaknya indikator formatif yang digunakan. Pengukuran signifikansi dilakukan dengan menghitung nilai t atau $\mathrm{p}$ (probabilitas kesalahan) (Santosa, 2018). Berikut ini hasil nilai outer weight dan signifikansinya untuk Struktur modal, Profitabilitas dan Nilai Perusahaan.

Tabel 4

Nilai Outer Weight dan Signifikansinya

\begin{tabular}{|l|l|l|l|l|l|}
\hline & $\begin{array}{l}\text { Original } \\
\text { Sample } \\
(\mathrm{O})\end{array}$ & $\begin{array}{l}\text { Sample } \\
\text { Mean } \\
(\mathrm{M})\end{array}$ & $\begin{array}{l}\text { Standard } \\
\text { Deviation } \\
(\text { STDEV })\end{array}$ & $\begin{array}{l}\text { T Statistics } \\
(\mid \mathrm{O} / \text { STDEV } \mid)\end{array}$ & P Values \\
\hline $\begin{array}{l}\text { DAR -> } \\
\text { Struktur } \\
\text { Modal }\end{array}$ & 0.466 & 0.491 & 0.177 & 2.635 & 0.009 \\
\hline $\begin{array}{l}\text { DER -> } \\
\text { Struktur } \\
\text { Modal }\end{array}$ & 0.593 & 0.560 & 0.181 & 3.284 & 0,001 \\
\hline $\begin{array}{l}\text { EPS -> Nilai Perusahaan } \\
\text { NPM -> } \\
\text { Profitabilitas }\end{array}$ & 0.026 & 0.028 & 0.018 & 1.440 & 0,150 \\
\hline $\begin{array}{l}\text { PRICE -> } \\
\text { Nilai } \\
\text { Perusahaan }\end{array}$ & -0.074 & -0.077 & 0.021 & 3.608 & 0.000 \\
\hline $\begin{array}{l}\text { PER -> Nilai Perusahaan } \\
\text { ROE -> } \\
\text { Profitabilitas }\end{array}$ & -0.048 & -0.060 & 0.026 & 1.866 & 0,000 \\
\hline $\begin{array}{l}\text { TobinsQ -> } \\
\text { Nilai } \\
\text { Perusahaan }\end{array}$ & 1.006 & 1.006 & 0.002 & 444.331 & 0,000 \\
\hline
\end{tabular}

Dari hasil pengolahan data di atas dapat disimpulkan bahwa beberapa indikator yang ada pada variabel laten nilai perusahaan belum memenuhi tingkat signifikansi dan nilai t-hitung yang kurang dari nilai t-tabel (1.65033). Artinya indikator-indikator dalam penelitian ini masih belum memenuhi signifikansi dan relevansi outer weight. Untuk dapat melanjutkan penelitian terhadap inner model indikator-indikator yang membentuk konstruk harus dapat memenuhi kriteria signifikansi, maka dengan demikian pertimbangan yang dilakukan adalah dengan menghapus indikator-indikator yang tidak signifikan sebagai langkah untuk 
melanjutkan penelitian. Hasil perolehan setelah eleminasi beberapa indikator pada variabel nilai perusahaan adalah sebagai berikut.

Tabel 5 Nilai Outer Weight dan Signifikansi Hasil Eleminasi

\begin{tabular}{|l|l|l|l|l|l|}
\hline & $\begin{array}{l}\text { Original } \\
\text { Sample } \\
(\mathrm{O})\end{array}$ & $\begin{array}{l}\text { Sample } \\
\text { Mean } \\
(\mathrm{M})\end{array}$ & $\begin{array}{l}\text { Standard } \\
\text { Deviation } \\
(\text { STDEV })\end{array}$ & $\begin{array}{l}\text { T Statistics } \\
(|\mathrm{O} / \mathrm{STDEV}|)\end{array}$ & $\begin{array}{l}\text { P } \\
\text { Values }\end{array}$ \\
\hline DAR -> Struktur Modal & 0.463 & 0.490 & 0.173 & 2.666 & 0.008 \\
\hline DER -> Struktur Modal & 0.596 & 0.563 & 0.176 & 3.393 & 0,001 \\
\hline $\begin{array}{l}\text { NPM -> Profitabilitas } \\
\text { PRICE Nilai }\end{array}$ & -0.077 & -0.079 & 0.022 & 3.575 & 0.000 \\
\hline $\begin{array}{l}\text { Rerusahaan -> Profitabilitas } \\
\text { ROB }\end{array}$ & 1.006 & 1.006 & 0.002 & 441.980 & 0,000 \\
\hline $\begin{array}{l}\text { TobinsQ -> Nilai } \\
\text { Perusahaan }\end{array}$ & 0,914 & 0,915 & 0,009 & 98,794 & 0,000 \\
\hline
\end{tabular}

Hasil perolehan pengolahan data hasil eleminasi indikatorindikator yang tidak signifikan diatas dapat sebagai acuan untuk melanjutkan untuk pengujian hipotesis penelitian ini karena seluruh indikator-indikator yang ada pada variabel laten menunjukkan hasil yang signifikan baik ditinjau dari segi nilai t maupun nilai p.

\section{Asesmen Model Struktural (Inner model)}

Setelah melakukan pengujian terhadap outer model, beberapa indikator yang tidak memenuhi syarat telah dieleminasi dan untuk pengembangan lebih lanjut dalam analisis ini, berikut diagram jalur yang telah dimodifikasi sesuai dengan uji outer model yang terbebas dari kolinearitas. 


\section{Gambar 2}

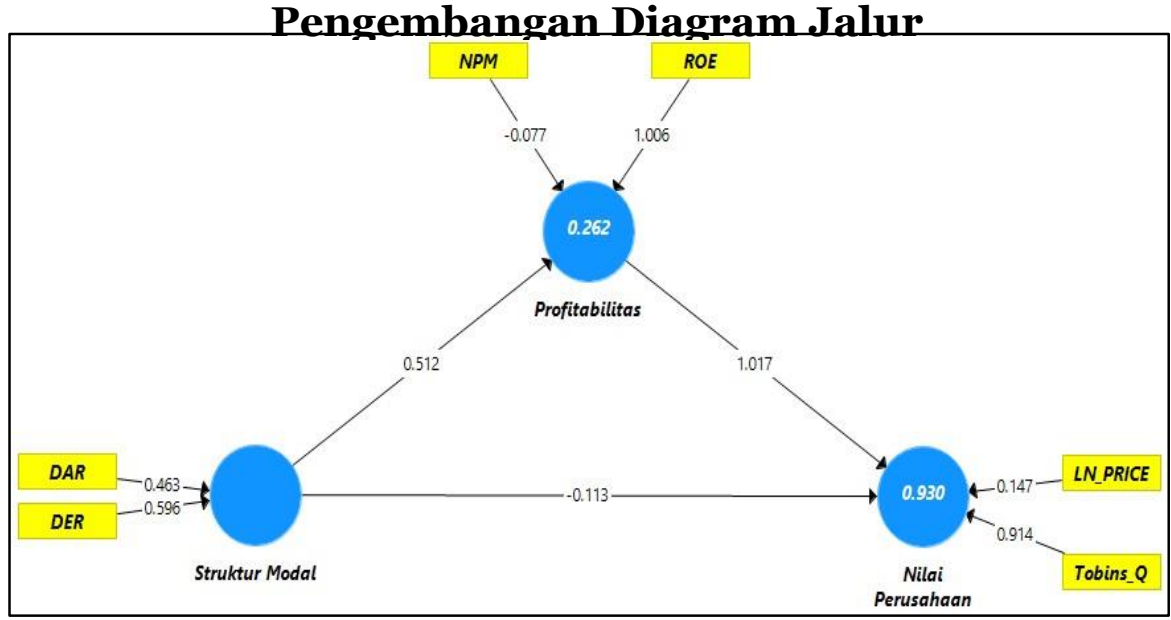

Asesmen model struktural (inner model) dapat diuji setelah pengujian pada outer model terpenuhi. Asesmen model pengukukuran adalah untuk mengetahui nilai koefisien jalur $(\beta)$ dan koefisien determinasi $\left(\mathrm{R}^{2}\right)$. Dengan diketahuinya koefisien jalur, kemudian dikombinasikan dengan uji $t$ dapat ditentukan signifikansi relasi antarpeubah sesuai dengan hipotesis yang diajukan. Model struktural dalam PLS dievaluasi dengan menggunakan $\mathrm{R}^{2}$ untuk konstruk dependen, nilai koefisien path atau t-values tiap path untuk uji signifikansi antar konstruk dalam model struktural. Nilai $\mathrm{R}^{2}$ digunakan untuk mengukur tingkat variasi perubahan variabel independen terhadap variabel dependen. Semakin tinggi nilai $\mathrm{R}^{2}$ berarti semakin baik model prediksi dari model penelitian yang diajukan. Untuk uji hipotesis dalam penelitian ini, telah ditetapkan nilai signifikansi sebesar $\alpha=0.05$ dan nilai t-tabel dengan total observasi sebesar 280 adalah 1.650333. Berikut ini hasil uji hipotesis untuk menunjukkan pengaruh strutur modal terhadap kinerja perusahaan.

Tabel 6 Hasil Uji Hipotesis

\begin{tabular}{|l|l|l|l|l|l|}
\hline Hipotesis & Relasi & Koefisien Jalur $(\boldsymbol{\beta})$ & thitung & sig & Kesimpulan \\
\hline H1 & $\begin{array}{l}\text { Struktur Modal -> } \\
\text { Nilai Perusahaan }\end{array}$ & -0.113 & 5.346 & 0.000 & Diterima \\
\hline H2 & $\begin{array}{l}\text { Struktur Modal -> } \\
\text { Profitabilitas }\end{array}$ & 0.512 & 8.029 & 0.000 & Diterima \\
\hline H3 & $\begin{array}{l}\text { Profitabilitas } \\
->\text { Nilai Perusahaan }\end{array}$ & 1.017 & 62.747 & 0.000 & Diterima \\
\hline H4 & $\begin{array}{l}\text { Struktur Modal -> } \\
\text { Profitabilitas } \\
->\text { Nilai Perusahaan }\end{array}$ & 0.521 & - & 0.00 & Diterima \\
\hline
\end{tabular}




\section{Pengaruh Struktur Modal terhadap Nilai Perusahaan}

Persamaan yang telah terbentuk dari hasil uji sebelumnya menunjukkan bahwa pengaruh antara struktur modal terhadap nilai perusahaan dapat dilihat pada persamaan berikut ini.

\section{Nilai Perusahaan $=-\mathbf{- 0 . 1 1 3}$ Struktur Modal + e}

Persamaan tersebut menunjukkan bahwa variabel struktur modal mempunyai pengaruh yang negatif terhadap nilai perusahaan, artinya ketika struktur modal perusahaan naik atau penggunaan utang di dalam perusahaan naik sebesar 1\% maka nilai perusahaan akan menurun sebesar 11.3\%. Berdasarkan uji hipotesis yang dilakukan maka hasil yang diperoleh dari nilai t-hitung adalah $5 \cdot 346$, maka dapat diinterpretasikan bahwa struktur modal perusahaan berpengaruh terhadap nilai perusahaan berdasarkan nilai t-hitung $>$ t-tabel $(5.346>1.6503)$ dan tingkat signifikansi berada diatas nilai signifikansi yang telah dibuat yaitu $0.000<$ o.05, kesimpulannya hasil hipotesis yang telah diajukan diterima.

\section{Pengaruh Struktur Modal terhadap Profitabilitas}

Persamaan yang telah terbentuk dari hasil uji diatas menunjukkan bahwa pengaruh antara struktur modal perusahaan terhadap profitabilitas dapat dilihat pada persamaan berikut ini.

\section{Profitabilitas $=0.512$ Struktur Modal + e}

Dari hasil persamaan yang telah terbentuk tersebut, diketahui bahwa variabel struktur modal mempunyai pengaruh yang positif terhadap nilai profitabilitas perusahaan, artinya ketika komposisi struktur modal suatu perusahaan / penggunaan utang meningkat sebesar 1\% maka nilai profitabilitas akan meningkat sebesar 51.2\%. Berdasarkan uji hipotesis yang dilakukan maka hasil yang diperoleh dari nilai t-hitung adalah 8.964, maka dapat diinterpretasikan bahwa struktur modal perusahaan memiliki pengaruh yang signifikan terhadap nilai perusahaan berdasarkan nilai t-hitung $>$ t-tabel (8.029 > 1.6503) dan tingkat signifikansi berada dibawah nilai taraf signifikansi yang telah dibuat yaitu $0.000<$ 0.05, kesimpulannya hasil hipotesis yang telah diajukan diterima.

\section{Pengaruh Profitabilitas terhadap Nilai Perusahaan}

Persamaan yang terbentuk pada pengaruh antara profitabilitas dan nilai perusahaan dapat dilihat pada persamaan berikut ini.

\section{Nilai Perusahaan $=$ 1.017 Profitabilitas + e}




\section{Pengaruh Kebijakan Struktur Modal terhadap Kinerja Emiten Syariah di Jakarta Islamic Index \\ Muhammad Arif}

Persamaan di atas menunjukkan bahwa profitabilitas yang dimiliki suatu perusahaan mampu menaikkan nilai perusahaan sebesar 10\%. Artinya ketika keuntungan perusahaan naik sebesar 1\% maka nilai perusahaan juga akan meningkat sebesar $101.7 \%$. Berdasarkan uji hipotesis yang dilakukan maka hasil yang diperoleh dari nilai t-hitung adalah 93.75, maka dapat diinterpretasikan bahwa profitabilitas perusahaan memiliki pengaruh yang signifikan terhadap nilai perusahaan berdasarkan nilai t-hitung > t-tabel $(62.747>1.6503)$ dan tingkat signifikansi berada dibawah nilai taraf signifikansi yang telah dibuat yaitu $0.000<0.05$, kesimpulannya hasil hipotesis yang telah diajukan diterima.

\section{Pengaruh Struktur Modal terhadap Nilai Perusahaan melalui Profitabilitas}

Persamaan yang terbentuk pada pengaruh antara Struktur modal terhadap nilai perusahaan melalui profitabilitas dapat dilihat pada persamaan berikut ini.

\section{Nilai Perusahaan $=0.521$ Struktur Modal $*$ Profitabilitas $+\mathbf{e}$}

Persamaan di atas menunjukkan bahwa penambahan utang pada struktur modal perusahaan mampu meningkatkan nilai perusahaan seiring dengan peningkatan profitabilitas perusahaan. Artinya utang memiliki dorongan yang sangat kuat terhadap kinerja yang diukur melalui rasio profitabilitas dan nilai perusahaan yang diukur dengan indikator harga saham dan Tobins Q. Bahkan ketika utang naik 1\% maka dapat meningkatkan profitabilitas dan nilai perusahaan sebesar $52.1 \%$ seraca bersamaan. Untuk hipotesis model ini diterima secara signifikan dengan tingkat signifikansi berada dibawah nilai taraf signifikansi yang telah dibuat yaitu o.ooo < 0.05 .

Selain koefisien jalur, pada model struktural (inner model) juga perlu dilaporkan koefisien determinasi $\left(\mathrm{R}^{2}\right)$ dari setiap peubah laten endogen. Berikut ini tabel nilai $\mathrm{R}^{2}$ pada model penelitian ini.

\section{Tabel 7}

Koefisien Determinasi dari Model Jalur ( $\left.\mathbf{R}^{2}\right)$

\begin{tabular}{|l|l|l|}
\hline Peubah Endogen & R Square & RSquareAdjusted \\
\hline Profitabilitas & 0.262 & 0.259 \\
\hline Nilai Perusahaan & 0.930 & 0.929 \\
\hline
\end{tabular}

Berdasarkan hasil output pengolahan data diatas koefisien determinasi $\left(\mathrm{R}^{2}\right)$ variabel profitabilitas dan nilai perusahaan menunjukkan nilai masing-masing sebesar 0.262 atau $26.2 \%$ dan 0.930 atau sebesar 93\%. Hal ini menunjukkan 
bahwa variabel eksogen yaitu struktur modal hanya mampu menjelaskan 26.2\% terhadap variabel profitabilitas. Sedangkan $73.8 \%$ dipengaruhi oleh variabel lain yang belum diteliti dalam penelitian ini. Dan koefisien determinasi $\left(\mathrm{R}^{2}\right)$ yang dimiliki variabel Nilai perusahaan menunjukkan bahwa variabel eksogen yang memiliki arah penelitian terhadap nilai perusahaan mampu menjelaskan sebesar 93\%. Sedangkan sisanya $7 \%$ lagi dipengaruhi oleh faktor-faktor lain yang tidak ada pada penelitian ini. Pada model SEM, nilai koefisien determinasi dari sebuah peubah endogen akan meningkat ketika sebuah peubah eksogen ditambahkan ke dalam model jalur yang akan diuji. Dengan demikian, uji $\mathrm{f}^{2}$ menjadi menarik untuk dilakukan guna melihat ukuran pengaruh $\mathrm{f}^{2}$ ketikasebuah peubah eksogen dihilangkan dari sebuah model jalur. Berikut ini hasil uji $\mathrm{f}^{2}$ pada penelitian ini:

Tabel 8

F-Square

\begin{tabular}{|l|l|l|l|}
\hline & NilaiPerusahaan & Profitabilitas & $\begin{array}{c}\text { Struktur } \\
\text { Modal }\end{array}$ \\
\hline Struktur Modal & 0.135 & 0.354 & \\
\hline Profitabilitas & 10.874 & & \\
\hline Nilai Perusahaan & & & \\
\hline
\end{tabular}

Sesuai dengan metode yang diterapkan Cohen (1998) pada pengujian $\mathrm{f}^{2}$, secara kualitatif nilai $\mathrm{f}^{2}$ dikelompokkan berdasarkan ukuran yaitu besar, sedang, dan kecil yang masing-masing setara dengan 0.35, 0.15, dan 0.02. Nilai $\mathrm{f}^{2}$ yang kurang dari 0.02 menunjukkan bahwa sebuah peubah eksogen tidak memiliki pengaruh terhadap peubah endogennya. Berdasarkan kategorisasi tersebut dapat dipahami bahwa peubah struktur modal memiliki pengaruh yang sangat kecil terhadap nilai perusahaan, peubah struktur modal memiliki pengaruh yang besar terhadap profitabilitas, dan profitabilitas memiliki pengaruh yang sangat tinggi terhadap nilai perusahaan.

\section{Kesimpulan}

Kesimpulan besar dalam penelitian ini menunjukkan bahwa struktur modal pada perusahaan penerbit saham syariah yang tercatat pada Jakarta Islamic Index (JII) periode 2014-2018 memberikan suatu hasil yang mengarah pada peningkatan kinerja perusahaan. Dengan menggunakan model Partial Least Square-Structural Equation Modelling (PLS-SEM), peneliti membuktikan bahwa terdapat bukti secara statistik yang didasari pada hasil pengujian yang telah dilakukan pada struktur modal dengan indikator Debt to Asset Ratio dan Debt Equity Ratio terhadap nilai perusahaan 


\section{Pengaruh Kebijakan Struktur Modal terhadap Kinerja Emiten Syariah di Jakarta Islamic Index \\ Muhammad Arif}

dengan indikator harga saham dan Tobins-Q melalui kinerja perusahaan yang diukur dengan rasio profitabilitas perusahaan yaitu Net Profit Margin dan Return on Equity. Hal tersebut dimungkinkan karena kinerja perusahaan yang digambarkan melalui rasio profitabilitas menjelaskan bahwa keadaan suatu perusahaan dalam kondisi yang menguntungkan atau tidak. Sebagai implikasi dari penambahan keputusan yang ada di dalam komponen struktur modal dijelaskan pada hasil penelitian bahwa setiap penambahan utang pada perusahaan penerbit saham syariah mampu mendorong kinerja perusahaan baik dari segi profitabilitas maupun dari segi nilai perusahaan.

Selain itu di sisi lain, hasil PLS-SEM menunjukkan bahwa dengan pengujian secara langsung variabel struktur modal justru memiliki pengaruh yang negatif terhadap nilai perusahaan. Hal tersebut dapat ditinjau melalui kacamata investor dengan melihat penambahan utang yang tidak disertai dengan peningkatan kinerja perusahaan maka perusahaan tersebut dinyatakan tidak layak untuk investasi karena tidak mampu memberikan return terhadap para pemegang saham. Hasilnya ketika rasio utang naik maka harga saham ataupun nilai perusahaan akan menurun.

\section{Daftar Pustaka}

Aziz, Musdalifah. et.al.,Manajemen Investasi, Fundamental, Teknikal, Perilaku Investor dan Return Saham, (Yogyakarta: Deepublish, 2015).

Baker, H. Kent \& Gerald S. Martin, Capital Structure and Corporate Financing Decisions, (Canada: John Wiley \& Sons, 2011).

Baxter, Nevins D, Leverage, "Risk of Ruin and The Cost of Capital", in The Journal of Finance, The American Finance Association, 1976. doi:10.1111/j.15406261.1967.tbo2975.x

Brigham, Eugene F. \& Joel F. Houston, Manajemen Keuangan, Edisi Kedelapan, Buku 2, (Jakarta: Erlangga, 2001).

Chen, Jian \& Roger Strange, "The Determinants of Capital Structure: Evidence form Chinese Listed Companies", in Economic Change and Resctrutring (2005) 38: 11-35. Doi 10.1007/s10644-005-4521-7.

Ebaid, Ibrahim El-Sayed, "The impact of capital-structure choice on firm performance: empirical evidence from Egypt", The Journal of Risk Finance, Vol. 10 Issue: 5, 2009, pp.477-487. doi: 10.1108/15265940911001385

Fabozzi, Frank J. \& Pamela P. Peterson, Financial Management\& Analysis, (Canada: John Wiley \& Sons, 2003).

Fahmi, Irham, Pengantar Manajemen Keuangan, (Bandung: Alfaberta, 2013).

Fauziah, Fenty, Kesehatan Bank, Kebijakan Dividen dan Nilai Perusahaan: Teori dan 
Kajian Empiris, (Samarinda: RV Pustaka Horizon, 2017).

Fuad, M. et.al., Pengantar Bisnis, (Jakarta: PT. Gramedia Pustaka Utama, 2006).

Hamid, Masdiah Abdul. et.al., "Capital Structure and Profitability in Family and NonFamily Firms: Malaysia evidence", in International Accounting and Business Conference 2015, IABC 2015, Procedia Economics and Finance 31 (2015) 44-55.

Harahap, Sofyan Syafri, Analisis Kritis atas Laporan Keuangan, (Jakarta: Rajawali Pers, 2010).

Harmono, Manajemen Keuangan Berbasis Balanced Scorecard Pendekatan Teori, Kasus, dan Riset Bisnis, (Jakarta: Bumi Aksara, 2014).

Hunt, Peter A., Structuring Mergers and Acquistions: A Guide to Creating Shareholders Value, 5th ed. edition (Aspen Publisher, 2011).

Jaisinghani, Dinesh \& Kakali Kanjilal, "Non-linear dynamics of size, Capital structure and profitability: Empirical evidence from Indian Manufacturing sector", in Asia Pasific Management Review 22 (2017) 159-165.

Kraus, Alan \& Robert H. Litzenberger, “A State-Preference Model of Optimal Financial Leverage", in TheJournal of Finance, Vol. 28, No. 4 (Sep., 1973), pp. 911-922. doi: $10.2307 / 2978343$.

Lesambo, Felix I, Financial Statements, Analysis and Reporting, (Switzerland: Palgrave macmillan, 2018).

Malik, Mahfuja, "Value-Enhancing Capabilities of CSR: A Brief Review of Contemporary Literature" in Journal of Business Ethics, Vol. 127, Issue 2, pp 419-438 (2015), Retrieved from https://doi.org/10.1007 /s10551-014-2051-9

Miller, Merton H. \& Franco Modigliani, "Corporate Income Taxes and the Cost of Capital: A Correction", in The American Economic Review, 53.3, 1963, 433-43. doi:10.2307/1809167

Myers, Stewart C. \& Nicholas S. Majluf, "Corporate Financing And Investment Decisions When Firms Have Information The Investors Do Not Have", in National Bureau Of Economic Research 1984, Working Paper No. 1396.

Phillips, P.A. \& Sipahioglu, M.A, "Performance implications of capital structure: evidence from quoted UK organizations with hotel interests", in The Service Industries Journal, Vol. 24 No. 5, 2004, pp. 31-51. doi:10.1080/0264206042000276829.

Qureshi, M.A, "System Dynamics Modeling of Firm Value", in Journal of Modelling in Management, Vol. 2 No. 1, 2007, pp. 24-39. doi: 10.1108/174656607107 33031

Ross, Stephen A. et.al.,Fundamentals of Corporate Finance, (New York, McGraw-Hill, 2015).

Santoso, Agus, "Pengaruh Good Corporate Governance terhadap Nilai Perusahaan dengan Kinerja Keuangan Sebagai Variabel Intervening”, dalam Prosiding 
Seminar Nasional dan Call For Paper Ekonomi dan Bisnis (SNAPER-EBIS 2017), h.67-77.

Shahar, Wan Shahdila Shah Bt \& Sarifah Ismail Manja, "Determinants of Capital Structure" in Report On Economics And Finance, 2018, Vol. 4, no.3, 139-149. doi: 10.12988/ref.2018.8113

Vy, Le Thi Phuong \& Phan Thi Bich, Nguyet, "Capital Structure and Firm performance: Empirical evidence from a developing country", in Research in International Business and Finance, 2017. doi: 10.1016/j.ribaf.2017.07. 012. 